\title{
Merkel Cell Carcinoma of Cheek: 2 Case Reports
}

\author{
Hwibin Im, Byungjin Kang, Jae-Gu Cho, and Jeong-Soo Woo \\ Department of Otorhinolaryngology-Head and Neck Surgery, College of Medicine, Korea University, Seoul, Korea
}

\author{
협부의 Merkel 세포암종: 2 증례 보고 \\ 임휘빈 · 강병진 · 조재구 · 우정수 \\ 고려대학교 의과대학 이비인후-두경부외과학교실
}

\author{
Received February 24, 2017 \\ Revised March 3, 2017 \\ Accepted April 102017 \\ Address for correspondence \\ Jeong-Soo Woo, MD, PhD \\ Department of Otorhinolaryngology- \\ Head and Neck Surgery, \\ Guro Hospital, College of Medicine, \\ Korea University, \\ 148 Gurodong-ro, Guro-gu, \\ Seoul 08308, Korea \\ Tel $+82-2-2626-3187$ \\ Fax $+82-2-868-0475$ \\ E-maildiakonos@korea.ac.kr
}

\begin{abstract}
Merkel cell carcinoma (MCC) is a rare aggressive skin cancer with the mortality rate of 33\%. MCC was first described by Toker in 1972 as a trabecular cell carcinoma and is classified as a neuroendocrine tumor similar to small cell lung carcinoma and melanoma. The pathogenesis of MCC remains largely unknown. However, ultraviolet radiation and immunosuppression are likely to play a significant pathogenic role. The primary skin lesion is usually asymptomatic and it typically presents as a red or purple dome-shaped nodule. The management of MCC is controversial, however, local wide excision followed by radiotherapy is accepted as the primary treatment modality. The regional draining nodal basin is the most common site for recurrence. Therefore, sentinel lymph node biopsy is recommended in all cases, except for the clinically node-negative cases. We herein report two cases of MCC on the left cheek with different clinical manifestations. Korean J Otorhinolaryngol-Head Neck Surg 2018;61(10):546-51
\end{abstract}

\section{서 론}

1972년 Toker ${ }^{1}$ 에 의해 처음으로 보고된 Merkel 세포암종은 진피표피접합부(dermo-epidermal junction)에 위치한 Merkel 세포의 악성 변화로 생기는 일종의 신경내분비종양이다. 발병 률은 미국에서 10만 명당 0.45 명으로 매우 낮으며, 국내에서도 다양한 신체 부위에서 약 30예 정도가 보고되었다. ${ }^{2)}$ Merkel 세포암종은 대개 무통성의 적색 혹은 자색의 피부 결절로 나 타나는데, 신체 전역에 발생할 수 있으며 약 50\%에서는 일광 에 주로 노출되는 두경부 영역에서 발생한다.3) Merkel 세포 암종은 국소재발, 주위 림프절 전이, 원격 전이 등이 흔하게 발 생하는 특징이 있어 그 예후가 좋지 않다고 보고되고 있다." 따 라서 가능한 조기에 이를 진단하여 적절한 치료를 시행하는 것 이 중요하다.

This is an Open Access article distributed under the terms of the Creative Commons Attribution Non-Commercial License (https://creativecommons.org/licenses/by-nc/4.0) which permits unrestricted non-commercial use, distribution, and reproduction in any medium, provided the original work is properly cited.
Merkel 세포암종에 대한 치료는 아직 정립되어 있지 않지 만, 광범위한 수술적 절제를 시행하는 것이 그 치료로서 널리 받아들여지고 있으며, 주변 림프절 전이의 가능성이 높기 때문 에 감시 림프절 생검이 도움이 될 수 있다.5) 또한 국소 방사선 치료에 비교적 반응이 좋은 것으로 알려져 있다. ${ }^{6)}$ 저자들은 좌측 협부 피부에 발생한 Merkel 세포암종 2예를 경험하였는 데, 한 예에서는 다발성 경부 전이가 나타났고, 다른 예에서는 다발성 피부 병변을 보였다. 두경부 영역에서의 드물게 발생하 는 Merkel 세포암종의 다른 양상을 나타낸 두 증례를 보고하 고, 기존 문헌을 고찰하고자 한다.

\section{증 려}

\section{증 례 1}

70세 여자 환자가 3 개월 전에 발생한 좌측 협부의 종물로 본원 피부과로 내원하였다. 내원 당시 종괴는 좌측 협부, 비 구순구 측방으로 적색 결절의 형태로 나타났다. 환자는 이 병 
변에 대하여 통증을 호소하지 않았다. 피부과 외래에서 이 병 변에 대해 펀치 생검을 시행하였다. 조직검사상 헤마톡실린 에 오신 염색에서 진피 내로 침윤하는 작고 푸른색의 경계가 불 분명한 세포가 관찰되었고, cytokeratin 20(CK20)과 다양한 neuroendocrine marker에 대한 면역조직화학염색에 양성을 보였으며, 폐의 소세포암종에서 특징적인 thyroid transcription factor-1(TTF-1)에 음성 결과를 보여 Merkel 세포암종에 합 당하였다(Fig. 1). 당시 시행한 경부 전산화단층촬영검사 및 양


Fig. 1. The microscopic finding images. H\&E stain, small blueish color hyperchromatic cells with obscure boarder $(\times 400)(A)$. CK20 immunohistochemistry showing positive result, dots-like appearance $(\times 400)(B)$. Synaptophysin (neuroendocrine marker) immunohistochemistry showing positive result $(\times 400)(C)$. TTF-1 immunohistochemistry showing negative result $(\times 400)(D)$. TTF-1: thyroid transcription factor-1, CK20: cytokeratin 20.


Fig. 2. Patient profile images. Initial physical exam showing $5 \times 5 \mathrm{~cm}$ hard, fixed, nontender mass at left submandibular area (A). Previous operative scar on left cheek area (B). 
전자방출 단층촬영상에서는 다른 주변 림프절 전이나 원격 전이는 발견되지 않았다. 본원 이비인후과에서는 성형외과와 협진하여 병변 주변 $1.5 \mathrm{~cm}$ 의 절제연을 갖는 광범위 절제술 및 인공 진피 이식술을 시행하였다. 수술 중 시행한 동결절편 검사에서 절제연에 병변의 침범이 없음을 확인하였다.

환자는 수술 후 2달 뒤 좌측 악하부에서 약 $5 \mathrm{~cm}$ 가량의 압 통이 없는 고정된 경성 종물이 촉지되어 본원 이비인후과로 내원하였다(Fig. 2). 초음파 유도하 조직생검을 시행하였고, 이 전 좌측 협부 병변에 생겼던 Merkel 세포암종과 같은 조직병 리 소견을 보였다(Fig. 3). 경부 전산화단층촬영검사 및 양전 자방출 단층촬영을 재시행하였고, 검사상에서 좌측 level $\mathrm{IA}, \mathrm{IB}, \mathrm{II}$ 및 이하선 내에도 다발성 림프절 전이가 확인되었 다(Fig. 4). 환자는 좌측 이하선 전절제술과 좌측 목의 level IA, IB, II, III에 대한 선택적 경부 절제술을 시행받았다. 또 한 수술 후 한 달가량 지난 시점부터 총 $6160 \mathrm{cGy}$ 의 방사선 량과 2 순환의 etoposide를 병합한 보조 화학방사선 치료를

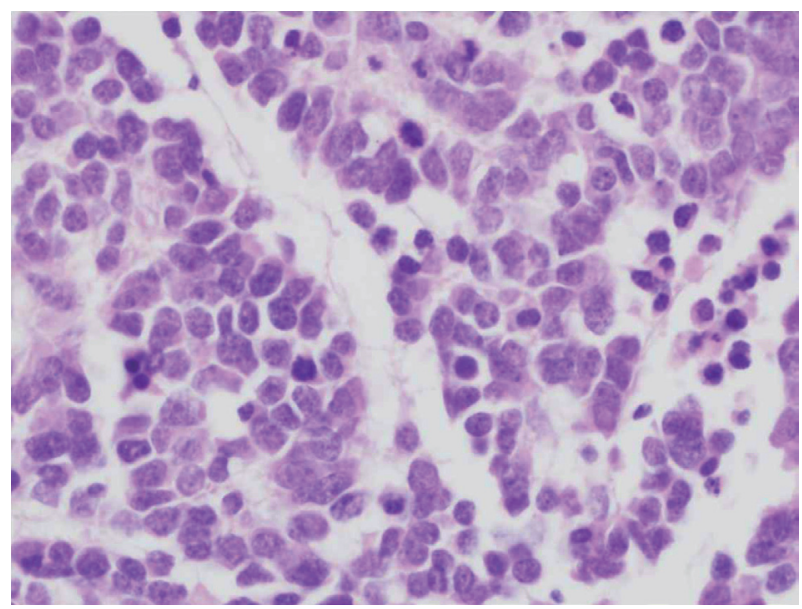

Fig. 3. Microscopic image of sono-guided neck biopsy, small blue colored and uniform size cell with vesicular nucleus, multiple small nucleoli and numerous mitoses (H\&E stain, $\times 400)$.

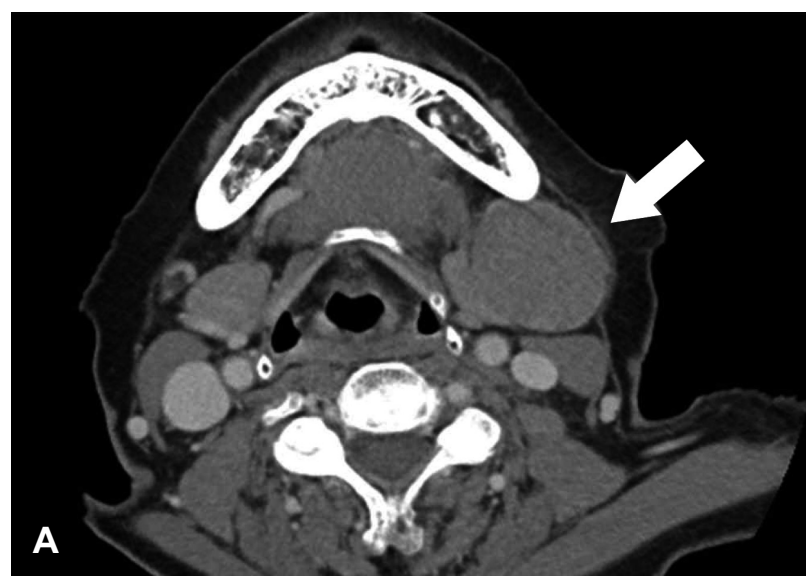

시행받았다. 환자는 현재 약 10 개월가량 재발 없이 외래 추적 관찰 중이다.

\section{증 례 2}

82세 여자 환자가 5개월 전에 발생한 좌측 협부의 종물을 주소로 내원하였다. 환자는 타원에서 이 병변에 대해 보존적 치료를 하였으나 그 크기가 점점 증가하여 본원 피부과로 내 원하였다. 내원 당시 좌측 협부 중앙부에 약 $3 \mathrm{~cm}$ 크기의 무 통성 적색 결절이 발견되었다. 시행한 이학적 검사에서 좌측 측두부에도 약 $7 \mathrm{~mm}$ 정도 크기의 비슷한 양상의 결절이 추 가적으로 발견되었다(Fig. 5). 환자는 외래에서 좌측 협부 병 변에 대한 펀치 생검을 시행하였다. 조직검사상 헤마톡실린 에오신 염색상 거품핵(vesicular nucleus)과 다수의 작은 핵소 체를 갖는 일정하게 작은 크기의 세포가 관찰되었고, CK20과 다양한 neuroendocrine marker에 대한 면역조직화학염색에 양성을 보였으며, 폐의 소세포암종에서 특징적인 TTF-1에 음 성 결과를 보여 Merkel 세포암종에 합당하였다(Fig. 6). 당시

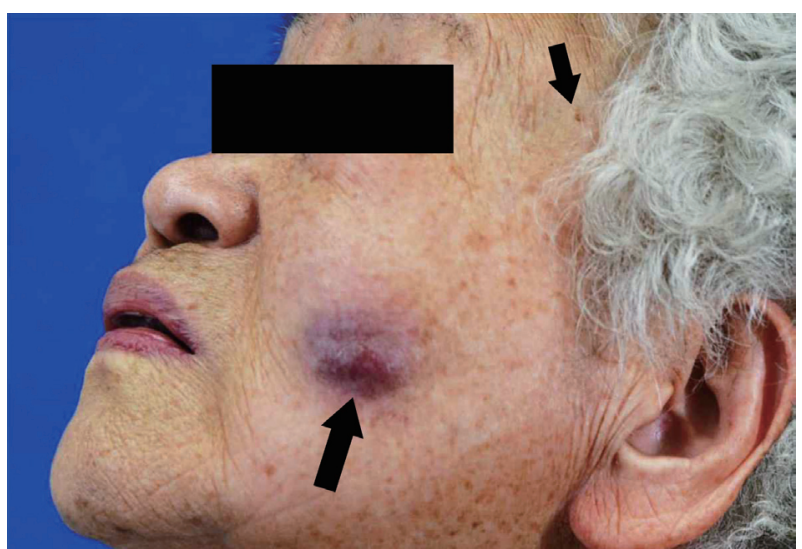

Fig. 5. Patient profile image. Initial physical exam showing $3 \times 3$ $\mathrm{cm}$ mobile, rubbery, nontender mass at left cheek dermis and another $7 \mathrm{~mm}$ nodule at left temporal area (arrows).

Fig. 4. CT axial view showing $3.1 \times 3.5 \times 3.6 \mathrm{~cm}$ sized relatively homogeneous enhancing mass (arrow) in inferior aspect to $\mathrm{Lt}$. SMG $(\mathrm{A})$. Multiple LN enlargement in left level IA, IB, II, intraparotid nodes (arrows) (B). Lt.: left, SMG: submandibular gland, LN: Iymph node. 
시행한 경부 전산화단층촬영검사 및 양전자방출 단층촬영 상에서는 좌측 협부 및 측두부의 피부 병변 이외의 다른 주 변 림프절 전이나 원격 전이는 발견되지 않았다(Fig. 7).
환자는 4년 전 심근경색으로 관상동맥우회로조성술을 시행 받았으며, 3년 전 우측 폐 선암종으로 본원 호흡기 내과에서 방사선 치료를 받은 과거력이 있었다. 환자 및 보호자의 수술

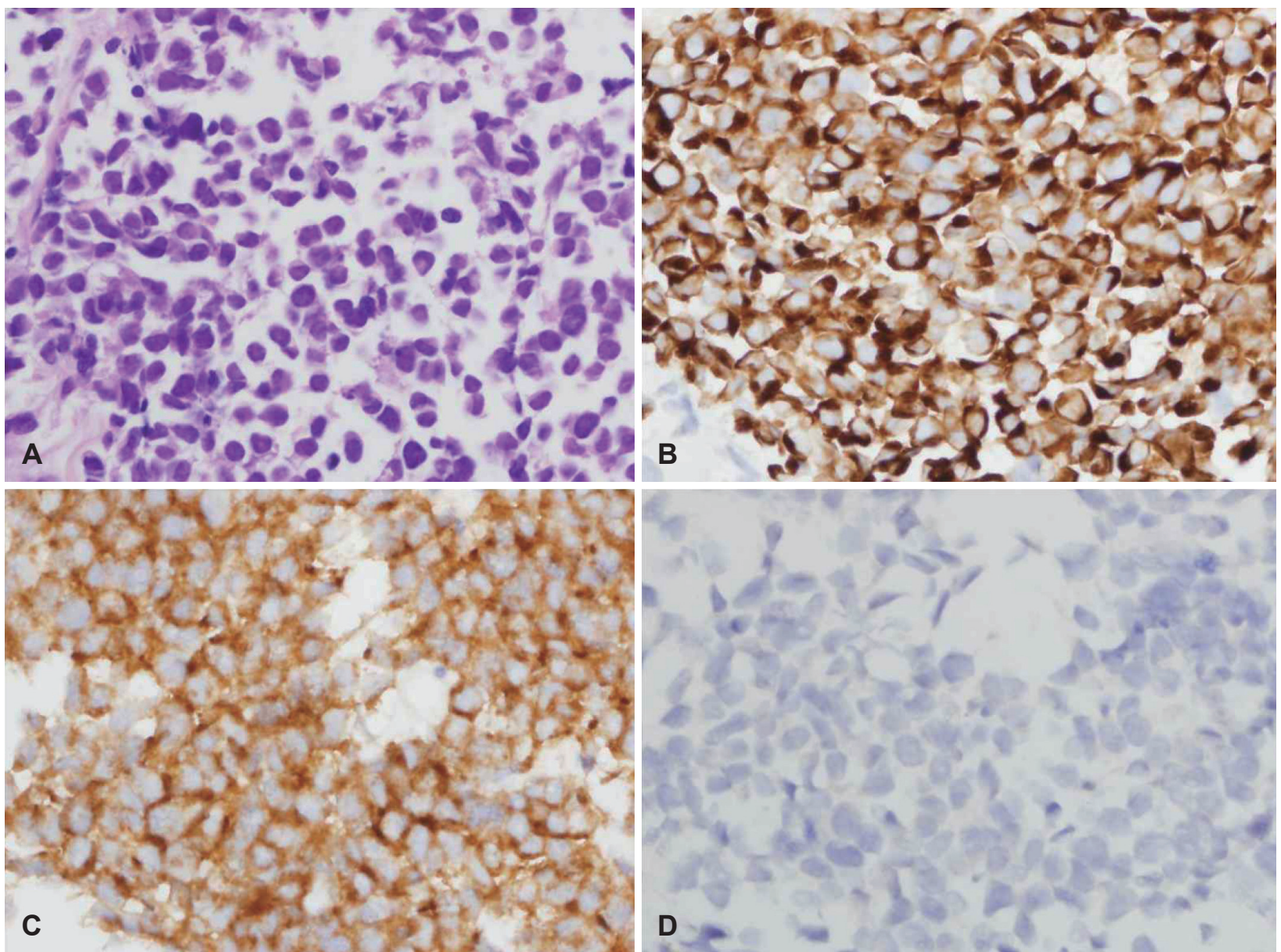

Fig. 6. The microscopic finding images. H\&E stain, small and round to oval cells of uniform size with a vesicular nucleus and multiple small nucleoli $(\times 400)(A)$. CK20 immunohistochemistry showing positive result $(\times 400)(B)$. Synaptophysin (neuroendocrine marker) immunohistochemistry showing positive result $(\times 400)(C)$. TTF-1 immunohistochemistry showing negative result $(\times 400)(D)$. TTF-1: thyroid transcription factor-1, CK20: cytokeratin 20.


Fig. 7. CT axial view showing $1.7 \times 2.6 \times 2.3 \mathrm{~cm}$ sized, well enhancing mass, in left cheek area (arrow) $(\mathrm{A})$ and another $7 \mathrm{~mm}$ sized small nodule with enhancement in left temporal area, dermis level (arrow) (B). 
에 대한 부정적 의견과 함께, 환자가 고령임을 고려하여 방사 선 치료를 계획하였고, 안면부와 측두부에 총 방사선량 6000 $\mathrm{cGy}$ 의 방사선 치료를 시행하였다. 방사선 치료 후 좌측 협부 의 종물 크기는 CT상으로 측정이 되지 않을 정도로 감소하 였으나 좌측 측두부의 종물의 크기는 변화가 없었다. 하지만 방사선 치료를 마친 후 6개월째 시행한 경부 컴퓨터단층촬영 상 좌측 악하부에 새롭게 발생한 약 $1.5 \mathrm{~cm}$ 의 경부 림프절 전 이 의심소견이 발견되어 경부 초음파 유도 세침흡인검사를 시행하였고, 전이성 Merkel 세포암종으로 최종 확인되었다. 그러나 환자 및 보호자는 이에 대하여 수술을 포함한 치료를 더 이상 원하지 않아 경과 관찰하고 있는 상태이다.

\section{고 찰}

Merkel 세포암종은 크기가 급격하게 증가하는 붉은 색상의 결절성 피부병변을 특징으로 하며, 병변에 대해서 환자가 자 각하는 증상은 적거나 거의 없다. Merkel 세포암종은 50세 이 상의 고령층에서 흔하게 발생되며, 후천성면역결핍증후군, 만 성림프구성백혈병 혹은 장기 이식 환자와 같이 면역이 저하되 어 있는 환자에서 더 잘 발생하는 경향이 있다. ${ }^{7)}$

병리학적으로 보았을 때, Merkel 세포암종은 폐의 소세포암 종, 유암종, 부속기관암종, 역형성암종, 악성림프종, 다른 고분 화 신경내분비암종 등 다른 악성 질환과의 감별이 필요한 것 으로 알려져 있는데, 이는 면역조직화학염색법을 통해 감별 할 수 있다. ${ }^{8)}$ Merkel 세포암종은 cytokeratin 8, 18, 20에 대 해 대부분 잘 염색되는 편이며, CK20은 특히 Merkel 세포암 종을 비롯하여 위나 장의 상피, 비뇨기의 상피와 혀의 미뢰 등 에서만 제한적으로 나타나기 때문에, 폐의 소세포암종과의 감 별 진단에 도움이 되고 있다. ${ }^{78)}$ 한편 CK20에 음성을 보이는 드문 Merkel 세포암종의 경우에는 소세포암종에서 흔히 발 현되는 TTF-1을 이용한 면역조직화학염색을 통하여 감별할 수 있다." Chromogranin-A, neuron-specific enolase, somatostatin, neurofilament, CD56, synaptophysin 등의 다 양한 neuroendocrine marker들 또한 이용될 수 있지만, 다 른 신경내분비 종양과 비교하여 Merkel 세포암종에 더 특이 적으로 발현한다고 할 수 없어 제한점이 있을 수 있다. ${ }^{8}$

Merkel 세포암종은 보고에 따라 50 80\%에서는 국소 병변 의 형태로 발견되지만, 그 증상이 뚜렷하지 않아 진단이 늦어 질 가능성이 있다. 또한 Merkel 세포암종은 약 10 30\%가량 에서 주변 림프절 전이를 보이며, $6 \%$ 이하에서 원격 전이의 가 능성이 있다. ${ }^{10)} \mathrm{Merkel}$ 세포암종으로 진단된 환자에서 예방적 경부 절제술을 시행하였을 때, 약 20 50\%가량의 환자에서 잠 재 경부 림프절 전이가 발견되었다는 보고가 있다. ${ }^{5,10)}$ Merkel
세포암종이 국소 병변인 경우 5년 생존율은 90\% 정도이지만, 주변 림프절 전이가 있는 경우는 52\%로 낮아지고, 원격 전이 가 있는 경우에는 $10 \%$ 미만의 5년 생존율을 보이고 있어 그 예후가 급격히 악화되는 특성이 있다. ${ }^{11}$ 국내에서도 원발병변 과 림프절 전이에 대한 절제술과 술 후 방사선 치료 및 화학 요법을 모두 시행하고도 다발성 원격 전이가 발생하여 사망하 였던 사례가 보고되었던 바 있다. ${ }^{12}$

예후에 미치는 영향을 고려하였을 때 적절한 Merkel 세포암 종의 치료를 결정하기 위해서는 병변의 범위를 명확하게 파 악하여야 한다. 드문 발병률로 인해 치료방법이 확립되어 있지 않으나, 기본적으로 피부에 국한된 병변일 경우는 1 2 cm 이 상의 변연부를 포함한 광범위 절제술을 시행하고, 추가 국소 방사선치료를 하는 것을 제안하고 있다.13) 하지만 안면부나 일 부 두경부 영역에서는 적절한 변연부를 확보하기 어려울 수 있 기 때문에 Mohs 수술법을 이용할 수도 있다. ${ }^{14)}$ 두경부 영역에 발생하였을 때 잠재 림프절 전이의 가능성이 있기 때문에 예 방 경부 림프절 절제술 혹은 감시 림프절 생검을 시행할 것 을 제안하는 보고들이 있으며, 대부분의 경우 추가 경부 방사 선 조사 혹은 동시 화학방사선조사를 시행하였다고 보고하고 있다.1.15) 항암 화학 치료의 Merkel 세포암종에서의 역할은 아 직 불분명하지만, 국소 치료가 불가능한 환자에서 완화치료 로 사용할 수 있다.

본 보고의 첫 번째 증례는 이전 원발 병변에 대해 광범위 절제술을 시행하였지만, 잠재 림프절 전이에 대한 고려를 하 지 않아 수개월 내에 경부 림프절 전이가 발견되어 내원한 환 자이다. 이 증례를 통하여 문헌 고찰에서 언급한 대로, 두경 부 영역에서 발견된 피부 병변이 Merkel 세포암종으로 진단 되었을 경우에는 반드시 경부 림프절 전이를 의심하여야 하 고, 감시 림프절 생검 등의 후속 조치를 고려해야 함을 알 수 있었다.

두 번째 증례에서는 좌측 협부 피부에서 발견된 Merkel 세 포암종이 동측의 측두부에도 소결절의 형태로 발견되어 Merkel 세포암종이 다발성으로도 발생할 수 있음을 알려주고 있다. 이 환자는 수술적 치료를 거부하여 원발 부위에 대한 방사선 치료를 시행하였으며, 현재 방사선 치료 후 10 개월째 원발 부 위에 대한 악화 소견은 보이지 않고 있다. 그러나 방사선 치료 후 6개월째 시행한 경부 컴퓨터단층촬영검사상 좌측 악하부 의 재발이 확인되었다. 따라서 첫 번째 증례와 비교하여 두 번 째 증례에서는, Merkel 세포암종의 치료는 방사선 치료만으 로는 재발을 억제하기에 부족하고 원발 부위에 대한 광범위 수술적 제거와 함께 추가 방사선 치료까지 적극적으로 시행 하는 것이 효과적이라는 것을 보여주고 있다. 다만 병이 재발 한 좌측 악하부가 방사선 치료의 범위에 들어 있지 않았다는 
점과 방사선 치료를 받은 원발병변의 악화가 아직 관찰되지 않았다는 점을 고려한다면, 방사선 치료는 수술이 불가능한 환자에서 Merkel 세포암종의 대안적인 치료로 고려해 볼 수 있을 것이라고 생각한다.

또한, 특별한 증상을 호소하지 않을 수 있는 이 질환의 특성 을 감안하여 반드시 원발병변의 주변부 및 가능하면 전신을 진찰하여 다발성병변이 없는지 확인하는 것이 필요하다는 것 을 알 수 있었다. 비록 드문 발병률을 지닌 질환이지만, 두경 부 영역에 생길 수 있는 피부병변 중 이와 같은 특징을 가진 Merkel 세포암종은 반드시 감별과 적극적인 치료를 필요로 하기에 본 저자들이 경험한 2예를 보고하는 바이다.

\section{REFERENCES}

1) Toker C. Trabecular carcinoma of the skin. Arch Dermatol 1972; 105(1):107-10.

2) Woo KJ, Choi YL, Jung HS, Jung G, Shin YK, Jang KT, et al. Merkel cell carcinoma: our experience with seven patients in Korea and a literature review. J Plast Reconstr Aesthet Surg 2010;63(12):2064-70.

3) Pitale M, Sessions RB, Husain $S$. An analysis of prognostic factors in cutaneous neuroendocrine carcinoma. Laryngoscope 1992;102 (3):244-9.

4) Pagella F, Semino L, Corno S, Colombo A, Benazzo M. Merkel cell carcinoma of the auricle. Am J Otolaryngol 2005;26(5):324-6.

5) Gupta SG, Wang LC, Peñas PF, Gellenthin M, Lee SJ, Nghiem P. Sentinel lymph node biopsy for evaluation and treatment of patients with Merkel cell carcinoma: the Dana-Farber experience and meta- analysis of the literature. Arch Dermatol 2006;142(6):685-90.

6) Gillenwater AM, Hessel AC, Morrison WH, Burgess M, Silva EG, Roberts D, et al. Merkel cell carcinoma of the head and neck: effect of surgical excision and radiation on recurrence and survival. Arch Otolaryngol Head Neck Surg 2001;127(2):149-54.

7) Heath M, Jaimes N, Lemos B, Mostaghimi A, Wang LC, Peñas PF, et al. Clinical characteristics of Merkel cell carcinoma at diagnosis in 195 patients: the AEIOU features. J Am Acad Dermatol 2008;58(3): 375-81.

8) McCardle TW, Sondak VK, Zager J, Messina JL. Merkel cell carcinoma: pathologic findings and prognostic factors. Curr Probl Cancer 2010; 34(1):47-64.

9) Bobos M, Hytiroglou P, Kostopoulos I, Karkavelas G, Papadimitriou CS. Immunohistochemical distinction between Merkel cell carcinoma and small cell carcinoma of the lung. Am J Dermatopathol 2006; 28(2):99-104.

10) Pellitteri PK, Takes RP, Lewis JS Jr, Devaney KO, Harlor EJ, Strojan P, et al. Merkel cell carcinoma of the head and neck. Head Neck 2012; 34(9):1346-54.

11) Agelli M, Clegg LX. Epidemiology of primary Merkel cell carcinoma in the United States. J Am Acad Dermatol 2003;49(5):832-41.

12) Lee HH. A case of Merkel cell carcinoma with cervical lymph node metastasis. J Clinical Otolaryngol 2005;16:323-6.

13) Bichakjian CK, Lowe L, Lao CD, Sandler HM, Bradford CR, Johnson TM, et al. Merkel cell carcinoma: critical review with guidelines for multidisciplinary management. Cancer 2007;110(1):1-12.

14) Allen PJ, Bowne WB, Jaques DP, Brennan MF, Busam K, Coit DG. Merkel cell carcinoma: prognosis and treatment of patients from a single institution. J Clin Oncol 2005;23(10):2300-9.

15) Bichakjian CK, Harms KL, Schwartz JL. Selective use of adjuvant therapy in the management of Merkel cell carcinoma. JAMA Oncol 2015;1(8):1162-3. 